AÜIFD Cilt XLIII (2002) Sayı 2 s. 355-374

\title{
Aristoteles Mantığı ile Felsefe-Bilim İlişkisi
}

\section{İsmail KöZ}

Yrd. Doç. Dr., Ankara Universitesi İlâhiyat Fakültesi

e-mail:koz@divinity.ankara.edu.tr

The Relation of Aristotelian Logic to Philosophy and Science. It was a question much debated in antiquity whether Logic should be accounted a branch of philosophy. According to Aristotelian point of view, Logic is merely a preliminary to philosophical studies and Stoics unlike Aristotle called Logic a part of philosophy. For this reason It has always been discussed the relation of Logic to other sciences; whether their basic ideas and principles can be analytically derived from logic. This relation is an obvious subject in modern times for deeper investigations. Aristotle and his successors tried to make the Logic an instrument and art of reasoning in general. In their opinion The Logic was an organon of reasoning, enabling the logical connectives to be realized in the scientific disciplines.

Aristotle, in the syllogistic doctrine of his Prior Analytics he enunciates a number of general principles. He thinks of these principles as important, because they guarantee the validity of arguments. These arguments may be applied to all possible subject matters. The subject matter of traditional logic is merely the principles which govern the validity of inference. Traditional logic is concerned with the analysis of propositions and of proof with the attention to the form in abstraction from the matter. The logical relations 
which hold with regard to judgments, concepts are represented by rules whose interpretation is free from the ordinary language.

Key Words: Aristotelian Logic, branch of philsophy, art of reasoning, Organon, methodology, discipline, argument, validity, inference, syllogistic reasoning.

\section{1) Aristoteles Mantığının Özellikleri}

Antikçă̆ mantık ve felsefe ekolleri arasındaki en önemli problemlerden birisi mantık bir bilim midir? Yoksa sanat mıdır?, tartışmasıdır. Antik Yunan'da felsefî okullar arasında mantığın felsefeyle ilgisi üzerinde ortaya çıkan bu tartışma özellikle Antikçağ'ın iki ana mantık okulu olan Peripatetik okul ile Stoacı okul arasında gerçekleşmiştir. Asıl sorun mantığın felsefenin bir disiplini olup olmadığıdır. Birbaşka ifadeyle mantık felsefenin bir disiplini midir? Yoksa felsefe yapmanın, bilimi kurmanın metodu mudur?

Mantığın felsefe ile ilgisi konusunda üç temel görüş vardır: "Peripatetikler mantığın felsefenin yalnızca bir aleti olduğunu söylerken, Stoacılar mantığın felsefenin bir kısmı olduğu; Platoncular ise mantığın eşit olarak hem felsefenin bir kısmı hem de aleti olduğu görüşündeydiler. Aristoteles yorumcularından Ammonius, Platonculann fikrini kabul ederek şöyle bir uzlaştırma denemesine girmiştir: Eğer kıyası terimlerin içerikleri açısından ele alırsak o zaman mantığa felsefenin bir kısmı olarak bakabiliriz. Fakat kıyası semboller ile ifade edilen soyut kurallar olarak göruirsek, Peripatetiklerin Aristoteles'i takibederek yaptıkları gibi o zaman mantığı felsefenin bir aleti olarak kabul edebiliriz." 1

Aristoteles'in mantığı bir alet olarak değerlendirdiği çok açıktır. Bu da mantığ 1 bütün bilimlerin öncesine yerleştirmektir. Önce alet bilinecek ve kullanılarak felsefe ve bilim inşa edilecektir. Bu yönüyle onun mantığına felsefenin ve bilimin aleti anlamında Organon denmiştir. Ancak yine de Aristoteles mantık ile diğer bilimlerin ilişkisini tam bir şekilde açıklamadığı için konuyla ilgili önemli tartışmalar modern zamanlarda da hâlâ sürmektedir.

Mantığın kurucusu Aristoteles' in felsefe ve bilimi ile mantığı arasında tam bir uygunluk, karşılıklı ve birebir bağlantı görenler de vardır. Onda niteliğe dayanan (qualitative) bir bilimle yüklemli (predicative) bir mantık örtüşmektedir. Çünkü bu düşünüş sistemi, bu mantık sadece entelektüel bir

1. Jan Lukasiewicz, Aristotle's Syllogistic, Oxford The Clarendon Press, 1954, s. 13. 
merak üzerine değil, belirli bir görevi yerine getirmek için, bu felsefeyi düşünmek için kurulmuştur. Bu nedenle Aristoteles mantığına Organon, başka bir ifadeyle bilim ve felsefenin aleti denmiştir.2 Atademir ise, Kategoriler tercümesinin önsözünde şunları ileri sürmektedir: "Aristoteles, mantığı ne fizik, matematik ve metafizik gibi teoretik; ne ahlâk, iktisat ve siyaset gibi pratik; ne de retorik, şiir ve diyalektik gibi poetik bilimlerden saymamakla onu bir bilim olarak görmemiştir. Bundan ötürü ne ikili ne de üçlü bilim sınıflamalarında mantığa rastlanmamaktadır. Ona göre mantık bilimlerin girişi, aleti veya bilimin şekli ve hatta bütün bilimler bu alete muhtaç olduklarından bilimlerin bilimidir."3 Görüldüğü gibi mantığın bilimler karşısındaki konumunun ne olduğu ta başından beri tartışılan bir konudur. Modern zamanlarda da bu tartışmanın devam ettiğine şahit oluyoruz. Gelecekte de mantığın bilimler arasındaki yeri ve etkisinin önemli bir tartışma konusu olacağı muhtemeldir.

Mantık nedir? sorusu mantığın kuruluşundan beri üzerinde durulan önemli bir probleme işaret etmektedir. Mantık nedir, diye sorduğumuzda buna birbirinden farklı tanımlar verilmektedir. Bu nedenle mantıkta bir tanımlar çokluğundan bahsedebiliriz.

Mesela: 1) Mantık var olanın genel niteliklerinin bilimidir; 2) Mantık herhangi belirlenmemiş nesnenin fiziğidir; 3) Mantık, düşünüşün ideal kanunlarının bilimidir; 4) Mantık doğru düşünme sanatıdır ${ }^{4}$ gibi tanımlara rastlayabiliriz.

Birinci tanıma göre mantık, varlıkbilim, ikincisine göre çok genelleştirilmiş bir doğa bilimidir. Yukarıda da belirtildiği gibi mantığı nesnelerin fiziği olarak kabul eden anlayış onu nesnelerin varlığına ve nesnelerin kendi aralarındaki ilişkilere ait kanunların bütünü olarak görmektedir. Üçüncüsünde fizikötesi söz konusudur. Bir başka ifadeyle metafizik bir hüviyete bürünmektedir. Bu da demektir ki, mantık ideal bir varlık bilimidir; zihin tarafından bulunmuş ve kurulmuş değildir. O öyle varolduğu için zihin onu bulur ve bilir. Dördüncü tanımda mantık artık bilim değil ancak bir sanat yani sadece belirli bir amaca varmak, doğru düşünmek için konmuş bir takım kurallar bütünüdür. Bir başka ifadeyle bilimlere giriş, bir metot olması sözkonusudur. Aslında Aristoteles'in görüşü de bu sonuncusudur, denebilir.

Mantığın tanımı yapılırken, felsefenin diğer disiplinleriyle karşılaştırılması sözkonusudur: Mesela Kant'ın değerlendirmesinde Eski

2. Nusret Hızır, Felsefe Yazıları, 2. Bsk., İstanbul, Aralık, 1981, s. 229.

3. Aristoteles, Organon I, Kategoriler, Çev. Hamdi R. Atademir, M.E.B. yay., Istanbul, 1989, Önsöz, s.VIII.

4. Hizir, a.g.e., s. 224. 
Yunan felsefesi üç bilime aynlıyordu: "Fizik, etik ve mantık: Her akıl bilgisi ya içeriklidir ve bir nesneyi ele alır; ya da biçimseldir ve nesnelerde ayırım yapmaksızın, anlama yetisi ile aklın yalnız biçimiyle ve düşünmenin genel kurallarıyla uğraşır. Biçimsel felsefeye mantık denir. Belirli nesnelerle ve bu nesnelerin bağlı olduğu yasalarla ilgili olan içerikli felsefe de yine ikiye ayrılır. Çünkü bu yasalar ya doğanın ya da özgürlüğün yasalarıdır. İlk yasalara ilişkin bilime fizik, diğerlerine ilişkin olana ise etik denir. Mantığın, düşünmenin genel ve zorunlu yasalarının dayandığı temellerin deneyle bir ilgisi yoktur. Yoksa mantık anlama yetisi ve akıl için bütün düşünmede geçerli olan ve kanıtlanması gereken bir kurallar bütünü olamazd.." 5 "Deneye dayanan her felsefeye deneysel, öğretilerini yalnızca a priori ilkelerden çıkanı sunana ise saf felsefe denebilir. Bu sonuncusuna sırf biçimsel olduğu zaman mantık denir."6

Aristoteles'de gerçek varlığın, varlık olarak varlığın bilimi metafizik olduğundan mantık gerçek varlığın bilimi değildir. Fakat varlığın kanunlan düşüncenin de kanunları olduğundan varlık kanunlarıyla düşünce kanunlarının bu özdeşleştirilmesi sonucunda mantık metafizik veya ontolojik karakterine bürünerek objektif hakikatin bilgisi, aklî varlıkların bilgisi olmaktadır. Bu suretle o bilimin aleti olmakla kalmıyor, bilimin kendisini de konu olarak alıyor.? Hızır, Aristoteles'in mantı̆̆ın formel kaynağını duyulabilir denemede değil, varlığın ve kanunlarının ifadesi olan aklın kendisinde gördüğünü ileri sürer. Aristoteles mantık sisteminde duyulabilir denemeden çok aklın kendisinde bulunan kanunları ifade etmekten başka bir şey yapmamışıิır. ${ }^{8}$

Gerçekte Aristoteles'e göre aklı a priori olarak varlıktan ayrı, bağımsız düşünemeyiz. Varlıktaki düzen ve işleyiş düşünmemize de yansır. Ancak bu şekilde düşünen özne ile düşünülen nesne arasındaki karşılıklı bağıntı kavranabilir. Daha doğrusu akıl ve gerçeklik arasında uyum düşünülebilir. Gerçekliğin yapısı aklınkine uygun olduğundan mantık ilkeleri gerçek üzerine dayanmaktadır. Ve böylece mantık felsefenin bir disiplini olarak görülebilmektedir.

Buna ilaveten Aristoteles'in mantığı, fizik ve matafizik hakikatlere, ispat için uygulaması onda fizik ve metafizik hakikatlerin birbirine bağ $h_{ı}$ olduğu fikrine yolaçmıştır. Bunun neticesinde onun mantığını ilk formel bir

5. Immanuel Kant, Ahlak Metafiziğinin Temellendirilmesi, Çev. lonna Kuçuradi, H. Ü. Yay., Ankara, 1982, s. 1.

6. Kant, a.g.e., s. 3.

7. Aristoteles, Kategoriler, Atademir'in Önsözü, s.VIII.

8. Nusret Hızır, "Çağdaş Düşünce-Mantık Meselesi", tarihsiz, Yay. Haz. Efdal Emiroğlu, Fethi Baycın, ss. 22-23. 
mantık sistemi olarak görenlerin yanında, materyal bir karakterde olduğunu söyleyenler de çıkmıştır. Fakat mantığın bütün bilimler için bir ortak yöntem olması Aristoteles'de mantığın bir varlık bilimi gibi görülmesine neden olmamalıdır.

Aristoteles' in bilim yaparken genel anlayışın tersine duyumları göz ardı etmeden gözlemi, karşılaştırmayı deneme ve tümevanımı devamlı kullanmasına rağmen onu yalnız kıyas yoluyla ispatçı bir bilimin kurucusu, bir bilim teorisyeni olarak tahlil ve tenkit etmek âdet olmuştur.

Oysa Aristoteles madde kavramını öne sürerek farklı değişim biçimlerini ayırt etmiş, bunlan betimleyip tartışarak özcülüğü kurmuştur. Varlığın tümel yönlerini nesneye bağımlı kılmakla algıladığımız fiziksel dünyayı felsefe için çıkış noktası yapmıştır. Deneyi bilgiye temel yapan, maddeci gerçekçiliği bilinçli olarak ilk kuran yine Aristoteles'tir. ${ }^{9}$ Fakat yine de yeni bilimsel gelişmelerin ve metot anlayışlarının gerisinde kaldığ $\breve{l}_{1}$ iddia edilmiştir. Bunun sebebi de Aristoteles mantığının 2000 sene mümkün olan yegane mantık olarak kabul edilmesidir. Bu anlayış nedeniyle uzun asırlar boyunca mantık ne bir adım gerilemesi ne de bir adım ilerlemesi mümkün olmayan bir sistem kabul edilmiştir. Ortaçağ'da ise mantık tamamiyle bir şekilden ibaret kaldığından mantığın eşyanın derinliğine inmediği; hep bilimin dışında özlerle ve bilinen hakikatlerle uğraştığı fikri yerleşmiştir. ${ }^{10}$

Bunun sebebi Aristoteles'in bilgi ve bilim anlayışıdır. Çünkü onda bilimin konusu öz manasında olduğundan başka türlü olmayandır. $O$ bilmekten ispat vasıtasıyla bilmeyi kasteder, zorunlu sonucu vermesi için ispatı da değişmeyen öz üzerine kurar. Onun bütün sisteminin temelinde yatan anlayış, ilmin en öz vasf 1 "niçin"i göz önünde tutmaktır." Aristoteles bu niçinin bilgisini elde etmede sebeple özdeşleştirdiği özü yüklü bulunan orta terime ağırlık veriyor. Ona göre "orta terim" şekildir, özdür. ${ }^{12}$ Aristoteles için önce dikkat edilecek husus özün tasdiki meselesidir. Öz, bir varlığın zarunî karakterlerinin bütünüdür. İlmin konusu zorunlu ve tümel olan olduğu için özü bulmak gerekir. Çünkü ona göre kıyaslar prensip olarak hep formel özü alırlar, yalnız özün kıyası olabilir. ${ }^{13}$

9. Arda Denkel, Demokritos-Aristoteles (Ilkf̧ăgda Doğa Felsefeleri), 1stanbul, 1986, ss. 2, 87.

10. Hans Reichenbach, Lojistik, Çev. Vehbi Eralp, İstanbul, 1939, s. 45; Nusret Hızır, "Bir Mantık Tanımı Münasebetiyle", AÜDTCFD., C. V., say. 3, Mayıs-Haziran, 1947, s. 339.

11. Aristoteles, Organon IV, II. Analitikler, 3. Bsk., Çev.: H. Ragıp Atademir, İstanbul 1989, s. 27-30.

12. H. Ragıp Atademir, Aristo'nun Mantık ve Ilim Anlayısı, Ankara, 1974, s. 121.

13. Atademir, a.g.e., s. 120. 
Bu özün bilgisi de kıyasta "Birinci Şekil" ile elde edilir. Çünkü şekillerin en ilmî olanı budur. ${ }^{14}$ Kıyas, dedüksiyonun en mükemmel şeklidir, dedüktif delil türünden bir tanesidir. "Dedüksiyonda problem, ilk önermeler nasıl elde edilir. Dedüksiyonun bir yerden başlaması gerektiğinden, bu başlangıç ispat edilmemiş, ispattan farklı bir yolla bilinmesi gereken bir şeyle başlamalıdır. Aristoteles bu konuda öz (essence) kavramina dayaniyor. Bu da özel olaylardan elde edilen genel kavramlardır." 15 Öz'ün nasıl mantığın konusu olduğuna Husserl şöyle bir açıklık getirir: "Öz de rastlantısal olmayan, nesnel, zaman içinde değişmeyendir. Bu durumuyla mantığın konusudur. Nasıl öz, fenomenolojinin yöntemiyle dünyasal, olgusal niteliklerinden arıtılmışsa mantığın nesneleri de aynı niteliği taşırlar." 16

Şimdi önce Aristoteles'in kıyas teorisinin yapısını irdeleyelim. O, sözün, dille düşünce arasındaki münasebetin kısaca açıklamasından başlayarak kavram, önerme, kıyas ve ispat teorilerini kurmuştur. Çünkü onun mantık sisteminde kavramlar, önermeleri; önermeler de kıyasları oluşturur. Bu nedenle asıl amaç kıyasların incelenmesidir. Genelde klâsik mantığa karşı tenkitler kıyas teorisi üzerinde yoğunlaşmaktadır. Bununla birlikte gerek önerme, gerekse kavram anlayışı, onun varlık felsefesiyle yakından ilişkili bulunmuştur. Çünkü sisteminin temelinde kavram yatar; kavram da onun felsefesinde varlıkla sıkı sıkıya bağlıdır.

Kıyas dedüksiyonun en mükemmel şeklidir, demiştik. Aristoteles için dedüksiyon, mantıksal ispatın özünü oluşturur. İspatta sonuç, delilin öncülleri denen diğer önermelerden dedüksiyonla çıkarılır. Delil öyle kurulur $\mathrm{ki}$, öncüller doğru ise sonuç da zorunlu olarak doğrudur. Işte Aristoteles de bu ispat yapısının ne olduğunu ortaya koymak daha doğrusu ispat teorisini geliştirmek istemiştir. Çünkü Birinci Analitikler'in başında kıyas teorisini incelerken, bu incelemenin konusunun ispat olduğunu ve bağlı olduğu ilmin de ispatçı ilim olduğunu açıkça belirtir. ${ }^{17}$

Gerçekten de Aristoteles mantığının asıl ölmez yönü I. Analitiklerde geliştirmiş olduğu bu kıyas teorisidir. O, kıyası şöyle tanımlar: "Kıyas bir sözdür ki, kendisinde bazı şeylerin konulmasıyla bu verilenden başka bir şey, sadece bu veriler dolayısıyle gerekli olarak çıkar."18

Şimdi onun kıyasın kurulması ile ilgili söylediklerini ele alalım: Aristoteles'e göre "Bütün hâllerde herhangi bir sanatta veya herhangi bir

14. Aristoteles, II. Analitikler, s. 30.

15. Bertrand Russell, "Aristotle's Logic", The Basic Writings of Bertrand Russell içinde Ed. By. Robert E. Egner and Leaster E. Denon, Britain 1961, s. 279.

16. Ahmet Inam. Edmund Husserl Felsefesinde Manttk, Ankara, 1995, s. 44.

17. Aristoteles, I. Analitikler, s. 3, 9.

18. Aristoteles, a.g.e., s. 5 
ilimde olduğu gibi felsefede de yöntem aynıdır. Herhangi bir alanda kıyas oluşturulurken kıyasın ilkelerinin ne tarzda bulunduklanın ve onlan ne tarzda takip gerektiğini dikkate almalıdır. Bunu yaparken meselenin terimleri hakkındaki ilişkilere bakmalıdır. Mesela terimler arasında, inkâr ve tasdik arasında veya bütüncül (tümel) tasdik ile bölümcül (tikel) tasdik arasında ve bütüncül inkâr ile bölümcül inkâr arasındaki bağıntıya dikkat etmelidir. Fakat gereken şey iyice tayin edilen daha küçük sayıda terimler göz önünde tutmaktır. Fakat her bir ilimde o ilme has ilkeler çokluğu teşkil eder. Bunun sonucu olarak her bir konuya ait ilkeleri temin etmek denemeye aittir. Sözgelimi astronomi ilminin ilkelerini temin eden astronomik denemedir, çünkü ancak gök olguları uygun tarzda yakalandıktan sonradır ki, astronominin ispatlan keşfedilmiştir. Herhangi öbür sanat veya ilim için de bu böyledir. Bunun sonucu olarak o şeyin yüklemleri yakalanır yakalanmaz, derhal ispatlarını çıkarmak bize aittir." 19 Aristoteles'in bilimde ispata bu kadar önem vermesi onun bilimi aksiyomatik bir sistem olarak görmesi demektir. Şöyle ki, önce her bilimin temel ilkeleri (aksiomlar) denemeyle elde edildikten sonra o bilimin verileri bu aksiyomlar ışı̆̆ında sistematize edilmektedir. Bunu da kıyasla yapmaktadır. Ancak yukarıdaki alıntılarda ilk terimlerin tespiti önemli bir başlangıç olarak görülmektedir.

Lukasiewicz, Aristoteles'in kıyas doktrininde, terimler sınifları ifade ettiğinden tümel terimleri dikkate alıp tekil terimleri almadığını belirtir. Oysa iddiasına göre, tekil terimler tümel terimler kadar önemlidir. Sadece günlük hayatta değil fakat bilimsel araştırmalarda da önemlidir. Tekil terimlerin ve tekil önermelerin yerinin olmaması Aristoteles mantığının en büyük eksikliğidir. ${ }^{20}$

Aristoteles'e göre kıyas öncüllerden itibaren teşkil edilir. Şöyle ki, "filan yüklemle falan konu arasında bir münasebet tesis eden kıyas ise bu yüklemin bu konuya taalluk ettiğini gösteren öncüllerden hareket eder."2ı Bir konuyla ilgili öncülleri de şu tarzda seçmemiz gerekir: İlkin konunun kendini, tanımları ve nesnenin bütün özelliklerini; bundan sonra da mantıken nesneden çıkan bütün yüklemleri, ve bu sefer de nesnenin kendinin sonucu olduğu yüklemleri, aynı zamanda ona ait olmak imkânı bulunmayanlanı ortaya koymalıyız. 22

Öncül bir şey hakkında bir şeyi tasdik veya inkâr eden sözdür. Bu söz de ya tümel, ya tikel veya belirsiz olur. Bütün olarak alınan bir konuya

19. Aristoteles, Organon III, I. Analitikler, 4. Bsk., Çev.: H. Ragıp Atademir, İstanbul 1989 s. 91.

20. Lukasiewicz (1954), s. 4-6.

21. Aristoteles, I. Analitikler, s. 69.

22. Aristoteles, a.g.e., s. 79-80. 
yüklemeye veya yüklememeye tümel; bir bölüm olarak alınan veya bütün olarak alınmayan bir konuya yüklemeye veya yüklememeye tikel; tümellik veya tikellik gösterilmeden yapılan yüklemeye veya yüklememeye belirsiz denir. Bir terimin, başka bir terimin bütünlüğü içinde bulunduğunu söylemek, veya bir terimin tümel olarak alınan başka bir terime yüklendiğini söylemek aynı şeydir. Konuda öteki terimin hakkında tasdik olunmayacağı hiçbir bölüm bulunmadığı zaman bir terimin tümel olarak tasdik edildiğini söylüyoruz. Tersi de böyledir. Öncülün kendilerine dağıldığı şeye yani yüklem ile ister varlık kendine eklensin, ister var olmayan kendinden ayrılsın, yüklemin kendisi hakkında tasdik edildiği konuya terim denir. ${ }^{23}$

Görüldüğü gibi Aristoteles'in iyice tanımladığı öncüller sadece tümel terimlere tatbik edilebilir, tekil (individual-singular) terimlere değil. Açıktır ki, tümel ve tikel önermelerin terimleri tümel (universal) olmalıdır. Mesela o, "Bütün Callias'lar insandır" gibi anlamı olan bir önermeyi kabul etmez. Aristoteles terimlerle sınıflar arasında bağ kurar. Mesela Cleon, Callias gibi duyulur fertler hiç yüklem olamazlar; fakat başka şeyler onlara yüklem olabilir: Insan, hayvan gibi. ${ }^{24} \mathrm{Bu}$ konuyu Aristoteles şu ifadelerle açıklar: "Bir şey bir konuya olduğu gibi başka şeye de yüklendiğinden yüklem hakkında tasdik edilmiş olan her şeyin konu hakkında da tasdik edilmesi gerekecektir. Söz gelimi insan fert olarak alınan bir insana yüklenmiştir; bir yandan da hayvan, insana yüklenmiştir. Öyleyse fert olarak alınan insana hayvan da yüklenebilecektir. Çünkü fert olarak alınan insan hem insandır hem hayvan." 25 Böylelikle fert olarak insan, insan türüne girer ve bu türün cinsi de hayvandır. Buradan hareketle Aristoteles tür ve cinsleri de fertler gibi töz kabul etmiştir, ancak ikinci töz olarak.

Fakat Aristoteles burada şu açıklamayı getirme ihtiyacı hissetmiştir: "llk tözlerin belli bir varlık anlattıkları gerçektir. İkinci tözler (tür-cins), adlandınılmalarının şekli dolayısıyla, söz gelimi belli bir varlık anlattıklarına inanılabilir. Bununla beraber bu doğru değildir. Bu türlü deyimler çok bir nitelik ifade ederler, çünkü konu ilk tözde olduğu gibi bir tek değildir. Gerçekte insan bir çokluğa yüklenmiştir, hayvan da öyle. Bununla beraber tür ve cins niteliği mutlak şekilde ifade etmezler. Tür ve cins niteliği öze göre tayin ederler. Onların anlattıkları şey filan nitelikte bir özdür."26

Aristoteles'in bu cins ve tür anlayışının kıyasa nasıl yansıdığ 1 ve metafizik hatalara nasıl yolaçtığı hep tartışılan bir problemdir.

23. Aristoteles, a.g.e., s. 3-5.

24. Lukasiewicz (1954), s. 4-5.

25. Aristoteles, Kategoriler, s. 5.

26. Aristoteles, a.g.e., s. 13. 
Aristoteles şunu vurgular: Tekil terim doğru bir önermenin yüklemi olmaya uygun değildir. Aynı şekilde doğru bir önermenin konusu (subject) olamayan terimler de vardır. Aristoteles bu nedenle sisteminden bir önermenin konusu ve yüklemi olamayan terimleri çıkarmıştır. Aristoteles mantığının temel özelliği şudur: Aynı terim herhangi bir sınırlama olmadan konu ve yüklem olabilir. Bu nedenle kıyasın terimlerinin aynı cinsten olması gerekir.27

Klâsik mantıkta sıfata "yüklem" sıfatlanmışa da "konu" denir. Sıfatların yani yüklemlerin basit olanları vardır, mürekkep olanlanı vardır. Basit olanı kendisine bir tek sözle delâlet edilmiş olandır: Insan, hayvan, konuşan, beyaz, siyah gibi. Mürekkep kendisine mürekkep bir sözle delâlet edilendir. Konuşan hayvan, beyaz insan gibi. ${ }^{28} \mathrm{Bir}$ sıfat bir isim olabilir, fiil de olabilir. Yüklem ve konular aslında isim ve fiillerin manalandır. Yoksa isim ve fiil değillerdir. Ancak ilk bakışta isim ve fiillerle, yerlerini kelimelerin tuttuğu manaların kastedildiğini anlamak zor olunca isim ve fiiller sanki yüklemler ve konularmış gibi alınırlar. ${ }^{29}$

$\mathrm{Bu}$ ifadelerden açıkça Aristoteles'in mantık anlayışında varlık tasavvurlarının yönlendirici olduğu ileri sürülebilir. Hatta bu nedenle, Aristoteles tarafından geliştirilen dedüktif sistemin naturel (doğa üzerine) dedüksiyon sistemi olduğu; bu nedenle pek çok kuralları olsa da aksiyomatik bir sistem olmadığı $\mathfrak{t}^{30}$ iddia edilmektedir. Bu görüş doğru değildir. Çünkü Aristoteles geçerli bir çıkarımın dayandığı ilkeleri tespit ederken bu ilkelerin altında yatan temel bir aksiyom ortaya koymuştur:

"Bu aksiyom "ya hep ya hiç kuralt" (dictum de omni et nullo) olarak bilinir ve bir sıntfın tümü veya hiçbiri hakkındadır. Tabi bu aksiyom doğrudan yalnızca kıyasın "Birinci Şekli"ne uygulanır. Bazı kıyas kuralları da buradan elde edilir. Bu aksiyomu şu şekilde ifade edebiliriz: $E_{\breve{g}}$ er bir $M$ sinifinın bütün üyeleri $P$ sinıfinın belli bir özelliğine sahip (ya da sahip değil) ise ve bazı $S$ dediğimiz fertler de $M$ sinıfinın içinde ise bu fertler (S), P sinıfinın niteliğine sahiptir (ya da değildir). Açıktır ki, bir sınıfın tüm üyeleri hakkında söylenen şey, o sınıfin içinde bulunan diğer sınıfin tüm üyeleri hakkında da söylenebilir." 31

Aristoteles'de kategorik kıyas kategorik (basit) önermeler üzerine kuruludur. Kategorik önermeler de genellikle sınıflar hakkındaki ifadeler olarak kabul edilir. Şöyle ki, kategorik bir önerme bir sınıfın başka bir sınıfın içinde olup olmadığını bildirir. Bir sınıf, bazı özel niteliklerde ortak olan

27. Lukasiewicz (1954), s.7.

28. Farabî, et-Tavtia fi'l-Mantık, Farabi'nin Bazı Mantık Eserleri içinde, Neşr. ve terc. Mübahat Türker Küyel, Ankara, 1990, s. 24.

29. a.g.e., s.55.

30. John Corcoran, "Completeness of An Ancient Logic", The Journal of Symbolic Logic, Volume 37, Number 4, December 1973, ss.696-697.

31. L.S. Stebbing, A Modern Introduction to Logic, U S A, 1961, s. 86. 
bütün objelerin bir kolleksiyonudur. Sınıfların birbiriyle bağlandığı çeşitli yollar vardır. Eğer bir sınıfın bütün üyeleri diğer ikinci sınıfın da üyeleri ise birinci sınıf ikincisinde içerilmiştir denir. Bir sınıfın sadece bazı üyeleri başka bir sınıfın üyeleri ise onda kısmen içerilmiştir denir. Tabiki ortak hiçbir üyesi olmayan sınıf çeşitleri de vardır. İşte sınıflar arasındaki bu çeşitli ilişkiler dört kategorik önerme (tümel olumlu, tümel olumsuz, tikel olumlu ve tikel olumsuz) ile olumlu ya da olumsuz olarak gösterilir. ${ }^{32}$

Klâsik mantığa göre yalnız bir tek önerme biçiminin olduğu ileri sürülür. Bu da bir konuya bir yüklem veren biçimdir. Bu biçim, belli bir şeye nitelikler yüklemek için uygun olan bir biçimdir. Gerçekte Aristoteles’in mantığı yüklem mantığıdır. Yani temelinde bir konuyu bir yükleme bağın yardımı ile bağlayan yargılar bulunmaktadır. Aristoteles'in yüklem mantığına, sıfatı isme bir başka deyimle niteliği varlığa bağlayan bir felsefe ile bir bilim tıpatıp uymaktadır. Bu felsefe ile bu bilimde tabiatları gereği belirli bir niteliği taşıyan varlıklar vardır. 'Ateş sıcaktır', 'Kar soğuktur' önermelerinde olduğu gibi. Klâsik mantıkta bunun karşılığında 'Her a b'dir' önermesi bulunmaktadır. Başka türlü söylemek istersek şöyle deriz: a'lar sınıfının bütünü b'ler sınıfının içindedir. Bu felsefe ve bilime göre de öyle varlıklar vardır ki, bunlar belirli bir niteliği tabiatları gereği hiçbir zaman taşımazlar. Klâsik mantıkta bunların karşısında 'Hiçbir a, b değildir' başka bir deyimle a sınıfının hiçbir öğesi b sınıfının içinde değildir, önermesi bulunmaktadır. Gene bu bilim ve felsefeye göre belirli bir niteliği ancak geçici olarak taşıyan varlıklar ya da o niteliği ancak sınıfın birkaç öğesinin taşıdığı durumlar vardır. Klâsik mantıkta bunların karşısında 'Bazı a lar b'dir' yahut a'lar sınıfının ancak bir bölümü o niteliği taşımaktadır, önermesi bulunmaktadır. ${ }^{33}$ Ancak önermelerin, sınıflar hakkında olumlu ya da olumsuz bir yargıda bulunması kıyasın formuyla ilgili bir şey değildir. Çünkü, kategorik bir kıyasın formu önermelerinin özel içeriklerinden bağımsızdır. Kıyasın geçerliliği ve geçersizliği sadece kendi formunun doğruluğu ve yanlışlığı ile ilgilidir. Bu durumda geçerli bir kıyas, formel olarak geçerli demektir.

Sinıf yorumunda, kategorik önermeyi oluşturan "konu" ve "yüklem" terimleriyle objeler sınıfı gösterilir ve önermede bu sınıflar hakkında bir yargı kabul ya da reddedilir. Doğru hüküm konu ile yüklemin, cümleyi meydana getiren kavramların objektif gerçekliğe uyacak şekilde, bir birlerine bağlanmaları yahut ta birbirinden ayrılmalarıdır. Böyle olunca kategorik

32. Irving M. Copy, Introduction to Logic, 2. Bsk, The Macmillan Company, Newyork, 1961, s. 134 .

33. Hizir (1981), s. 228-229. 
hüküm bir objeye bir sıfat yükleyen yahut da bir objeyi bir kavram altına sokan hükümdür. Aristoteles düşünce hayatındaki her ilerlemenin her düzenli bağlılı̆̆ın ancak hükümlerin mantık kaidelerine göre birbirlerine bağlanmaları sonucunda meydana geldiğini görmüştür. İki önermeyi bir birine bağlamak ve bunlar arasında mantıksal ilişki kurmak ancak kavramlarla mümkün olmaktadır.

Aristoteles'e göre ispatçı ve gerçek ilme ancak nesnelerin özüne cevap teşkil edecek olan tanımla ulaşılacağından ${ }^{34} \mathrm{o}$, tikel-tümel kavramlar arasında bağıntılar kurarak bunlarla şeyleri sınıflara ayınp tanımlıyor. ${ }^{35}$ Bu nedenle Aristoteles gerek mantıkta gerekse felsefede şeyleri sınıflama ve tanımlama ile işe başlar. Bu tanımlar da mantığın temel taşlan olan kavramlan oluşturur. Kavramlar da sinıflara tekabül eder.

Klâsik mantık öz anlayışı üzerine dayanan kavramlar arasındaki münasebet üzerine kurulu bir mantık yapısına sahiptir. Aristoteles'in hareket noktasını kavram felsefesi teşkil eder. Duyuların verilerinden başka bir bilgisi olmayan tekcil (individual) ler içinde tümel (universal) i; böylece öz (essence) ü veya kavramı kabul eder. ${ }^{36}$ Çünkü Aristoteles varlığı bir başka ifadeyle nesne düşüncesini kavramsal olarak çözümler. Aristoteles'in öncelikli amacı algılanabilen nesnenin varlık koşullanın ilkece yine algılanabilir karşılıkları olan kavramlarla açıklamak olmuştur. ${ }^{37}$ En temel ilkelere öğe olan kavramlar düşüncenin bölünemez ve çözümlenemez başlangı̧ noktalarıdır. ${ }^{38} \mathrm{Bu}$ itibarla Aristoteles mantığı, konu ve yüklem olarak kabul edilen iki genel kavram arasındaki formel bağın bağlı bulunduğu kurallardan bahseder. Bu durumda formel mantık kavramlar ve kavramlararası ilişkiler üzerinde önemle durur.

"Kavram bir objenin zihindeki tasavvurudur, buna fikir de diyebiliriz." "39 "Kavram zihnin sırf bir soyutlaması değildir. Kavram teşekkül edince, nesnelerin özüne bir cevap. zihnî bir karşıllk olur; bir başka ifadeyle nesnelerin tanımının zihindeki ifadesidir. "40

Yukarıda belirtildiği gibi "Kavram bir nesnenin zihindeki tasarımı olunca bu nesne ya bir küme bir başka ifadeyle sınıf, ya da bir bireydir. Bu durumda kavram, karşıllığı olan nesneyi gösterir. Örneğin "insan" teriminin gösterdiği nesne insan sınıfı, "Sokrates" teriminin gösterdiği nesne ise bir

34. Atademir, (1974), 49.

35. Hilmi Ziya Ülken, Genel Felsefe Dersleri, Ankara, 1972, s. 11.

36. Aristoteles, Kategoriler, Atademir'in Önsözü, ss. IX-X.

37. Arda Denkel, Düsüunceler ve Gerekçeler II, İstanbul, 1997, s. 45; Denkel (1986), ss. 2-3, 87.

38. Denkel, a.g.e., s. 126.

39. Necati Öner, Klasik Mantık, 6. Bsk., Ankara, 1991, s. 16.

40. Atademir, (1974), s. 101. 
birey olan Sokrates'tir. Gösterilen nesne bir sınıf olduğunda bu terimlere genel terim, buna karşıllk bir bireyi gösteren terim tekil terim sayılır." ${ }^{41} \mathrm{Her}$ genel terimin kaplamı bir sinıftır. Bu sınıf terimin uygulandığı nesnelerin kümesidir. Klâsik mantıkta bireyler tür denilen doğal sınıflara ayrılmıştır. Her tür, bir genel terimin gösterdiği nesnedir. Başka bir deyişle her tür, bir genel terimin kaplamıdır. Genel terimler arasındaki ilişkiler, bu terimlerin kaplamlan olan türler arasındaki ilişkilerdir.42 Görüldüğü şekliyle sınıflamada sözkonusu olan kavramların sınıflamasıdır. "Klâsik mantıkta kavramların kaplamını belirtmek onu sınıflandırmak demektir." ${ }^{43}$ "Kavramlar arası münasebetlerde de belirleyici olan cins ve tür fikirleridir." 44 Klâsik mantığın kavramların kaplamını dikkate alarak gerçekleştirdiği sınıflama anlayışına sınıflamanın objektif olmadığı, subjektif olduğu gerekçesiyle karşı çıkılmıştır. Bu tenkide göre bütün objeler için geçerli-doğru bir sınıflandırma mümkün değildir.

Nominalistlere göre kavramlar sadece adlar olduğu için obje çözümlemesine dayanan sınflama realiteye dayanmaz, keyfîdir. Aristoteles'e göre ise her obje yakın cinsini gerçek ve etkin öz olarak gelişmesini yöneten gizli neden olarak kendinde taşır. Aristoteles bilmeyi her şeyden önce objelerin çözümlemesine dayanan doğru bir sınıflama olarak görür. Bu nedenle onun çabası en yüksek ve en genel kavramdan aşağı doğru en alttaki cins kavramlarına kadar uzanan bir kavram zincirini oluşturmaktır. Ona göre bu kavram sınıflaması bütün objeler için geçerli olacak ve ilmî mümkün kılacaktır. ${ }^{45}$

Buradan anlaşılıyor ki, sınıflama işlemi belli sayıdaki hâllerin gözden geçirilmesiyle bütün hâller için düşünülebilecek bir genelleme imkânını vermektedir. Belli sayıda olan ile sınırsız sayıda olanı aynı sınıf içinde düşünmemizi sağlayacak olan da her hâlde tek fertlerin ayrı ayrı özellikleri değil de, genel özleri olacaktır. Çünkü sonsuz çokluklar alanıyla karşı karşıyayız. Sonsuz çokluklar da Aristoteles'de dedüktif bir düşünce ile ele alınacaktır. Ancak o, çokluğu birliğe irca ederken kavramlara dayanmaktadır. Çünkü kavramlar, onun anlayışında türlere ya da sınıflara tekabül eder.

Aristoteles'in tikel nesneler üzerine oturttuğu doğa felsefesi, mantıksal ve doğal bir biçimde "özcülük"e götürüyor. Bu öğretiyi terimleri, önermeleri

41. Teo Grünberg, Sembolik Mantık El Kitabı (Sembolik Mantığın Uygulamaları), 3. C., METU Press, Ankara, 2000, s. 27-28.

42. Grünberg, a.g.e., s. 30-33.

43. Doğan Özlem, Mantık, İstanbul, 1991, s. 100.

44. Necati Öner, Fransız Sosyoloji Okuluna Göre Mantığın Menşei Problemi, 2. Bsk, Ankara, 1977, s. 26.

45. Ernst Von Aster. Bilgi Teorisi ve Mantık, Çev. Macit Gökberk, Istanbul, 1972, ss. 77-78 
ve bunlarn anlamlarını inceleyerek, dil felsefesi ve mantık üzerinden kurar. Ontolojik sonuçları kavramları irdeleyerek çıkarır. Aristoteles temel önerme yapısı olan özne ve yüklem bağıntısına dayanarak bu ilişkinin kavramsal yapıya olduğu kadar varlığa ilişkin konulara da ışık tuttuğunu onaylıyor. ${ }^{46}$ Özne-yüklem bağıntısı varlığa şu şekilde ışık tutmaktadır: Özne yüklem bağıntısını dört biçimde yorumlayabiliriz: 1) Özne-yüklem bağıntısı bir niteleme bir başka ifadeyle yüklemin özneye bir nitelik vermesi şeklinde yorumlanabilir. 2) Bu bağıntı, bir üye ile bu üyenin ait olduğu sınıf arasındaki bağıntıdır. 3) Ya da bir alt sınıf ve bu sinıfı kapsayan sınıf arasındaki bağıntıdır. 4) Son olarak da özne-yüklem bağıntısı özdeşlik ilişkisine dayanmaktadır. Öyle ki; burada özne ve yüklemin delâlet ettiği sınıflar aynı şeyi simgelemektedir, birbirlerinin yerine kullanılabilir. Örneğin "İnsan akıllı bir hayvandır" önermesinde olduğu gibi. Burada özne ve yüklemi gösteren terimler arasında özdeşlik vardır. ${ }^{47}$

Hızır'a göre aslında sınıflar mantığı olan eski mantık sınıflar sınıfı ile sınıf içinde küçük sınıfı ayırdedememektedir. Onun gözünde hepsi sınıf içinde küçük sınıftır. Yeni mantık sınıflar hesabı ile çok önemli olan bu ayırmayı başarmıştır. Aristoteles sınıflar arasında belli türden bir bağıntı kabul eder. Mesela köpekler sınıfı memeli hayvanlar sınıfının içinde küçük bir sınıftır. Memeli hayvanlar ise hayvanlar sınıfının içinde küçük bir sınıftır. $O$ halde köpekler sınıfı da hayvanlar sınıfı içinde küçük bir sınıftır. ${ }^{48}$ Görüldü̆gü gibi Aristoteles'in sınıflar arasında kabul ettiği belli türden ilişki alt sınıf-sınıf bağıntısıdır. Bir sınıf ile başka bir sınıf arasında özdeşlik ilişkisine dayalı bağıntı ise daha çok tanım işlevi gören önermelerde söz konusudur. Diğer bütün bağıntılar alt sınıf-sınıf bağıntısına indirgenir. Bu da bazı sorunlara yolaçar. Mesela bir üye-sınıf bağıntısı ile alt sınıf-sınıf bağıntısı bir birine indirgenemez. Oysa Klâsik mantıkta bu böyledir. Halbu ki ikisi arasında yapı olarak çok fark vardır. Şöyle ki, alt sınıf-sınıf bağıntısı geçişli (transitive) olduğu halde, üye-sınıf bağıntısı (her zaman) geçişli değildir. Bunu şu ömekle açıklayabiliriz: Oktay A derneğinin, A derneği de $B$ dernekler federasyonunun üyesi ise Oktay'in B demekler federasyonunun üyesi olduğunu söyleyemeyiz. Çünkü kişiler değil ancak demekler, B dernekler federasyonunun üyesi olabilirler. Oysa, tüm memeliler omurgalı ve tüm omurgalılar hayvansa, tüm memelilerin hayvan olduğu kesinlikle söylenebilir. ${ }^{49}$ Fakat daha önce de gördüğümüz gibi Aristoteles tekil

46. Denkel, (1986), s. 211-212.

47. Cemal Yıldırım, Mantık El Kitabı, İstanbul, 1976, s. 43-44.

48. Hizir (1981), s. 233-234.

49 Yildırım (1976), ss. 44-46. 
terimlerle yapilan önermeleri kabul etmeyip sadece tümel ve tikel kavramlarla kurulan önermeleri kıyaslarda kullanmaktadır. Bu da eleştiri konusu olmaktadır. Bütün bunlardan dolayı Aristoteles mantığı, soyutlayıcı sınıflar mantığı olarak görülmektedir. Bunun yanında sınıflamanın subjektif olduğu, Aristoteles felsefesinin özelliklerini yansıttığı ileri sürülmektedir.

\section{2) Mantık Bilim İlişkisi}

Aristoteles'in mantığının, onun felsefesiyle, bilim anlayışıyla iç içe olduğu ve kendi felsefesini yansıttığı tenkidi sıkça yapılır. Aristoteles, algılanan şeyleri kavramlar hâlinde derleyip sınıflandırarak yeni bilgilere varmaya çalışmıştır. Bunu yaparken de kullandığı alet, nitelikçi ve sınıflayıcı kıyas teorisidir. Oysa Aristoteles, mantığı diğer bütün felsefe disiplinlerinden ayırmaya çalışmış; onu varlıkla ve bilgiyle ilgili bir alan değil, daha çok düşünme sanatı olarak görmüştür. Ne var ki, kıyas teorisinin bu nitelikçi ve sınıflayıcı özelliği zamanla formel olma özelliğini gölgede bırakmıştır.

Hızır'a göre niteliksel ilişkilere tatbik olunan mantık öze ve yüklemlere dayanan bir nitelikler mantığı veya varlık değerlerine dayanan sinıflamalar mantı̆̆ıdır. Yüklemlerin sınıflaması, tecrübe dünyasındaki ve hükümlerimiz arasındaki bütün bağıntılann ve modalitelerin her durumunu ne temsil edebilir ne de hepsini içine alabilir. Sınıflamalar mantığı ve bunun sonucu olarak tabi geleneksel mantık, özlerin bir sınıflaması olarak göz önünde tutulursa ona özün mantığı adı verilebilir. Çünkü, bu mantık, öze ait değerlere yöneltilmiş varlık değerlerinin münasebetlerinin mantığıdır. $O$ fonksiyonlardan çok varlığı ele almaktadır, hatta fonksiyonu varlığa indirgemektedir. Bunun aksine olarak modern bilim fonksiyonlarla ilgilenmek üzere özler ve yüklemleri bir kenara bırakmıştır. Ona göre "Güneş Aydınlatıcıdır" demenin hiçbir manası yoktur. Önce önemli olan bu fenomenik fonksiyonun analizidir. Güneşin ve ışı̆̆ının fenomenik tabiatıdır. ${ }^{50}$

Modern bilimin gelişmesiyle birlikte yeni bir düşünme şekli ortaya çıkmıştır. Yukanda da belirtildiği gibi klâsik mantık varlık değerleriyle idare edilen düşünce kanunlarını açıklamıştır. Bunun aksine olarak modern bilim olgularla ve onların matematik münasebetleriyle ilgilenmektedir. Öyleyse burada yeni bir düşünce şekli vardır. Fakat bu düşünce şekli hiçbir zaman birinciyi dışanda bırakmıyor; bilakis içine alıyor. Klâsik felsefenin konusu mutlak değerdir. Bilimin konusu göreli olgudur. Yeni konuya yeni bir mantık lazımdır. ${ }^{51}$ Çünkü, "eski mantık" bağıntıları yazmayı da hesaplamayı da

50. Nusret Hızır, "Çağdaş Duşünce-Mantık Meselesi", Haz. Efdal Emiroğlu-Fethi Baycın, th., ss. 5, 14-15.

51 H1zır, a.g.e., s. $11-12$ 
başaramaz. Çünkü o, her türlü bağıntıyı niteliğe indirger: 'a, b'den büyüktür' önermesinde b'den büyüktür parçasını a'nın bir tek niteliği olarak alır ve b'den büyüktür'ün bütünü, bir tek sözcükmüş gibi a'nın yüklemi olur. Burada, b'nin a'dan küçük olduğunu önermenin anlamından kavrıyor, ama bunu bir işlemle çıkaramıyoruz. Yeni mantık genel bağlantılar kuramını kurmuştur. Bu kuram çoğu bilimlerde düşünüş ve araştırma aleti olarak kullanılmaktadır..$^{52}$ Oysa daha önce klâsik mantık bilimler için bir alet olarak kullanılmaktayd1, hatta bilimlerin metodu olarak kabul görüyordu.

"O kadar ki, Aristoteles, mantığı fizik ve metafiziğ̈i izah için metot olarak kullanıyordu. Onun mantı̆̆ı, batı ve doğu Ortą̧ağı' nda bir alet olarak telakki edilmişve bütün bilimsel faaliyetler için metot olarak rağbet görmüş̧ür. ${ }^{n 53}$

Bu nedenle Ortaçağ skolastik düşüncenin en çok metod anlayışı tenkit edilmektedir. Renaissance yeni bilgiye ulaştıracak yeni bir metot ararken, skolastiğin kullandığı formel mantığa özellikle onun kıyas teorisine karşı çıkılmıştır. Çünkü Ortaçağ düşüncesi formel mantığı bir tartışma tekniği haline getirince; bilgi elde etmede sürekli kavramlarla çalışarak deney ve gözleme önem vermemiştir. ${ }^{54} \mathrm{O}$ kadar $\mathrm{ki}$, mantığın uygulaması ve önermelerin oluşturulması konusunda pek dikkat gösterilmeyip, bu konudaki hataların artması sonucu bazı metafizik prensipler üzerine kurulan garip sonuçlar yaygınlaşmıştır, artık duyulur âlemden bahsederken bile $\mathrm{d}_{1}$ ş dünyaya müracaat edilmeyerek kıyasla bilgi elde etme yoluna gidilmiştir. ${ }^{55}$ Böylelikle mantık tamamiyle bir şekilden ibaret kalmış, eşyanın derinliğine inmediği, hep bilinen hakikatlerle uğraştığı ve bilimin dışında özlerden bahseden bir düşünüş sistemi olduğu fikri yerleşmiştir. Sonuçta da formel mantığın esaslarının yetersizliği fikri metodoloji konusunu gündeme getirmiştir. ${ }^{56}$

Ortaçağ'da bilimler için Aristoteles mantığı yeterli görülürken Renaissance ile birlikte tabiat bilimlerindeki gelişme karşısında metot olarak yetersizliği ortaya çıktı ve bu nedenle yeni metot arayışları başladı. Öner'e göre bu meteodoloji fikirleri aslında formel mantığın bir açıklamasıdır. Yeniçağ'da bilimlerin metotları üzerindeki bu çalışmalar formel mantığı açıklamış, Aristoteles mantığının kötü kullanılmasına bir ölçüde engel

52. Hizur, (1981), s. 233.

53. Necati Öner, Tanzimattan Sonra Türkiye'de Illim ve Mantık Anlayışı, Ankara, 1967, s. 85.

54. Macit Gökberk, Felsefe Tarihi, 5. Bsk., Istanbul, 1985, s. 240-243.

55. Ali Sedat, Mizanu'l-Ukul Fi'l-Mantık ve'l-Usul, İstanbul, 1303, s. 7.

56. Hans Reichenbach, Lojistik, s. 45; Carnap, Rudolf, "Eski Mantık-Yeni Mantık", çev. Macit Şükrü, Felsefe Yıllı̆̆ı II. İstanbul, 1935, s. 236; Hızır, Nusret, "Bir Mantık Tanımı Münasebetiyle", AÜDTCFD., C. V, sayı: 3; s. 339. 
olmuştur. Bu nedenle metodoloji çalışmaları yeni bir mantık olarak değil de klâsik mantığın ıslahı olarak değerlendirilmelidir. 57

Aristoteles' in akılyürütme teorisine karşı çıkanlanın başında Galilei (1564-1642)'nin çağdaşı Francis Bacon (1561-1626 ve Descartes (15961650) gelir. Onlar mantığı metot olarak yetersiz görmüş ve yeni metot arayışlarına başlamışlardır. Bunlardan Bacon kıyas teorisi yerine tümevarımı esas alıp geliştirmeye çalışmıştır. ${ }^{58}$ Öner, Bacon ile başlayan yeni mantık çalışmalarının sebebini, mantığın kendi içinde bir gelişmesi olarak değil de, bilimsel faaliyetlerin zorlaması ve bu faaliyetlerin gerektirdiği ihtiyacı karşılamak için eski mantığı tamamlama gayreti olarak zikretmektedir. ${ }^{59}$

Descartes, Aristoteles'in kıyas mantığı yeni bilimi kurmaya elverişli olmadığından, ulaşmak istediği o sarsılmaz bilime ancak matematiğin yürüdüğü yolla vanlacağına inanmaktadır. $O$, bilgilerimiz arasında yalnızca matematiğin sağlam temellere dayandığını, felsefede doğru ve şüphe götürmez bilgilere ulaşmak istenirse, matematik metodun bütün bilimlere uygulanması gerektiğini düşünmüştür. Matematik onda genel düşünüş yöntemi basamağına yükseltilmektedir 60 Çünkü rasyonel bir bilim olan matematik, disiplinlerin en sistemlisidir. Netice itibariyle, Descartes kıyas teorisi yerine ideal bir metot olarak matematik dedüksiyonu getirmiştir. Bundan dolayı onun mantık ve felsefe sahasında açtığı çığıra "mathematisme" adı verilmektedir. Bir başka ifadeyle onun metodu genelleştirilmiş matematik dedüksiyondur.

Tabiat artık matematik bağıntılar sistemi olarak görülmektedir; Insan zihni en açık olarak nicelik bağıntılanını görebildiğinden nitelik bakımından tabiat her insana farklı farklı görünecektir. Buna karşın matematik tabiat görüşünde nesneleri ölçülebilen, sayıya vurulabilen yönleri ile yani nicelikleri bakımından kavramak esastır. Bu anlayışta tabiatın objeleri arasındaki sınırları belirleyen bunların ölçülebilen yönleridir. Bu ölçülebilen büyüklüklerin yasaları matematik olarak formüllenirse o zaman bu yasalar aynı kesinlikle bütün tabiata uygulanabilecektir. Oysa Aristoteles nesnelerin ana çizgisini niteliklerde buluyordu. Böyle bir felsefenin de ölçülebilen yönleri değil de nesneye özelliğini kazandıran niteliğini arayacağ açıktır. ${ }^{61}$

57. Öner, (1967), s. 85; Öner (1991), s.10.

58. Öner, (1991), s. 10; Gökberk (1985), s. 240.

59. Öner (1967), s. 85.

60. Hilmi Ziya Ulken, Mantık Tarihi, Istanbul, 1942, s. 134; Eralp (1947), s.2; Hızır (1981), s. 29.

61. Gökberk, (1985), s. 254-255; Eralp(1947), s. 40. 
Ortaçağlardaki Aristoteles fiziği Platoncu bir biçimde yorumlanarak, nesnenin formel yönü üzerinde durulmuştur. Burada formel yönün ve niteliklerin soyut ve kavramsal oldukları fikri vardır. Ortaçağ fiziğine tepki olarak kurulan Yeni-Çağ doğa bilimi, yapısal açıklama ile Aristoteles'in nesne çözümlemesini uzlaştırırken, madde düşüncesini ön plana çıkarmıştır. ${ }^{62}$

Aristoteles mantı̆̆1, Galilei-Newton biliminden beri bilimin soyut iskeleti olmaktan çıkarak bilimin dişında özlerden haber veren bir düşünüş sistemi olarak kalmıştır. Onaltıncı yüzyılın sonunda Galilei cisimlerin serbest düşüşlerini açıklayan yasayı buldu. Bu buluş Aristoteles fiziğinin sonu demektir. Cisimlerin neden düştüğünü değil nasıl düştüğünü meydana çıkarmayı amaç edinen Galilei, ağır cisimlerin düşüşünü doğru olarak betimlemek için olayın bütününü zaman (t), ivme (g), yol (s) gibi ölçülebilen öğelerine ayırmış ve onu bu öğeleri içine alan bir matematik fonksiyon şeklinde $\left(s=1 / 2 \mathrm{gt}^{2}\right)$ yeniden kurmuştur. Demek ki, Galilei Aristoteles'in yüklem mantığının, en ufak bir fonksiyon bağıntısını yazamadığını görerek, onu sadece bir yana itmiş, yerine matematiği koymuştur. Bu davranış ile matematik yeni bilimin mantığı olmuştur. $O$ zaman bir ikilik meydana gelmiştir. Bilimler, klâsik mantığa arkalarını dönünce mantık töz (cevher), ilinek (araz), sıfat, öz-nitelik, geçici nitelik gibi kavramların sözkonusu olduğu fizikötesine yerleşmiştir. Öte yandan matematik geliştikçe bilimin mantığı karakterini kazanmıştır. ${ }^{63}$

Fakat fenomenleri matematikle çözümlemeye kalkmak her zaman mümkün olmayabilir. Bazı olaylar çok karmaşıktır ve aralarındaki bağıntılar matematik kalıplara, formüllere sıkıştırılamaz. Biyolojik olayları bunlara örmek gösterebiliriz. Ruhsal olaylar da ölçüye imkan vermeyecek tabiatta sırf niteliklerden ibarettirler. Bu yüzden bu tür olaylan da matematik formüllerle izah edemeyiz.64 Matematiği ilgilendiren nokta bütün (fizik, kimya, biyoloji v.b) bilimlerin her birine mahsus olan araştırma tekniği diyebileceğimiz şeyler değil her birinde kullanılan çıkarım yollandır. Mantık da doğru düşünme sanatı, akılyürütmenin bilimi daha doğrusu geçerli çıkarımları sağlayan kural ve ilkelerin bilimi ise her bir bilimde yapılan çıkanmların denetlenmesini sağlayacaktır. Geçerli çıkarım şekillerini veren mantık, deney verilerini onlara içerik katmadan düzenlemelidir.

Acaba mantığın bilimlerle ilişkisi nasıl olacak; bilimlere katkısı ne olacak? Bu konular çok tartışmalıdır ve henüz sonuçlandırılmış da değildir.

62. Arda Denkel, Düşünceler ve Gerekçeler, Istanbul, 1997, s. 49.

63. Hizır (1981), s. 230-236.

64. Eralp (1947), s. 43. 
Geçmişte biliyoruz ki Aristoteles, mantığı fizik, metafizik hakikatlere tatbik etmiştir. Bu nedenle onun düşünce sisteminde mantık, bilimlerden ayrı bir konuma sahiptir. Bütün bilimler için ortak bir alet, bir metottur; bilimlere giriştir.

Her bilim disiplini, ayrı ayn kendi gerçeklerini ifade eden önermeler arasında tutarlılık gözeterek mantıksal bir sistem oluşturur. Bu sistemin mantıkî örgüsünü denetlemek, işleyişini düzenlemek elbetteki mantık kuralları olmaksızın imkansızdır.

Şafak Ural'a göre mantık, dili sembolik hâle getirmekte böylece dili kullanarak yaptığımız akılyürütmelerini formel işlemler halinde ifade etmek ve denetlemek imkanını vermektedir. Böylece mantık dediğimiz sembolik sistem, formel (matematik, geometri) ve formel olmayan (fizik, kimya, biyoloji gibi deneysel bilimler ve sosyal bilimler) bilimlerde uygulanarak bu disiplinlerdeki akılyürütmelerin ne şekilde olduğunu, kavramları arasındaki ilişkileri ortaya koyabilme imkânı vermektedir. ${ }^{65}$

Bazı filozoflar mantığın kendine özgü bir alanı, yapısı olduğunu, hiçbir bilime dayanmadığını ${ }^{66}$ öbür yandan da en genel durumu ile bilimlerin olabilirliğinin ideal koşullarını araştırdığını belirtir. Bunun yanında mantık bilimlerin ortak anlam dokusunu, bilimleri birbirine bağlayan formları belirleme ödevini üstlenir ${ }^{67}$

Carnap da mantığ 1 felsefe yapmanın metodu olarak görmektedir. Ona göre yeni mantığın amacı kısaca tecrübî ilmin önerme ve kavramlarının mantıkî analizinden ibarettir, denebilir:

"Mantıkî tahlille tecrübî ilmin kaziyelerini aydınlatmak, teferruatile: kaziyeleri aksamina (mefhumlara) ayırmak, mefhumların adım adım daha esasl mefhumlara; kaziyeleri adım adım daha esaslı kaziyelere irca etmek. Mantık diğerleri yanında sadece bir felsefe disiplini değildir, bilakis açıķ̧a diyebiliriz ki; mantık felsefe yapmanın metodudur." 68

Genellikle mantık, doğru düşünmenin yöntemini veya doğru düşünmenin kurallarını konu edinen bilim olarak tanımlanır. Teo Grünberg, aynı zamanda mantık, 'bilgilerimizi elde etmek için kullandığımız araçlardan biri olarak da tanımlanır', derken şu ayrıma da dikkati çeker:

"Mantik, bilgilerimizin fikarım yoluyla yani dolaylı olarak haklt gösterilmesini sağlayan bir yol veya yöntemdir. Mantık doğrudan doğruya çıkarım süreçleri ile değil, yalnızca çıkarımların geçerliliği ile ilgilenir. Çıkarınların gę̧erliliğini amaçlayan mantı̆̆ın ikinci bir işlevi de herhangi bir metni ve söylemi oluşıran önermelerin

65. Şafak Ural, "Sembolik Mantık ve Uygulaması", Felsefe Arkivi, Sayı: 26'dan Ayrı Basım, İstanbul, 1987, s. 143.

66. Inam (1995), s. 41 .

67. A.g.e., s. 68-70.

68. Camap, Eski ve Yeni Manıı, s. 246. 
birbiriyle uyumlu veya tutarlı olmasım sağlamaktır. Sonuç olarak mantık, çıkarımların geçerliliği ile önerme kümelerinin tutarlth $\breve{g} ı n$ denetleyen yöntem veya geçerlilik ile tutarsizlığı belirleyen kuralları konu edinen bilim olarak tanımlanabilir. "69

Klâsik mantığın, mantıktan bugün beklenen bu görevler için, Ortaçağ'da fizik metafizik gibi felsefe disiplinlerinde yeterli olduğu; hatta bütün bilimler için bir alet, bir metot, bilimlere bir giriş olarak genel kabul gördüğü belirtilmelidir. Ancak Renaissance'tan itibaren, felsefe ve bilimlerde meydana gelen değişmelerle birlikte yeni metot arayışları; bunun neticesinde de yeni mantık arayışlarının başgösterdiğini görüyoruz. Yeni bilim için yeni bir mantık fikri başlangıçta cazip görünürken zamanla yeni mantık çalışmalarının aslında tek bir mantık biliminin birer uzantısı olduğu fikri ön plana çıkmıştır.

\section{BİBLIYYOGRAFYA}

Ali Sedat, Mizanu'l-Ukul Fi'l-Manuk ve'l-Usul, Istanbul, 1303.

Aristoteles, Organon I, Kategoriler, Çev. Hamdi R. Atademir, M.E.B. yay., İstanbul, 1989.

Aristoteles, Organon III, I. Analitikler, 4. Bsk., Çev.: H. Ragıp Atademir, İstanbul 1989.

Aristoteles, Organon IV, II. Analitikler, 3. Bsk., Çev.: H. Ragıp Atademir, İstanbul 1989.

Atademir, H. Ragıp, Aristo'nun Mantık ve llim Anlayışı, Ankara, 1974

Camap, Rudolf, "Eski Mantık-Yeni Mantık", çev. Macit Şükrü, Felsefe Yıllı̆̆ı̆ II, İstanbul, 1935

Copy, Irving M. Introduction to Logic, 2. Bsk, The Macmillan Company, Newyork, 1961.

Corcoran, John, "Completeness of An Ancient Logic", The Journal of Symbolic Logic, Volume 37, Number 4, December 1973.

Denkel, Arda, Demokritos-Aristoteles (Ilkçağda Doğa Felsefeleri), İstanbul, 1986.

Denkel, Arda, Düşünceler ve Gerekçeler II, İstanbul, 1997.

Emst, Von Aster, Bilgi Teorisi ve Mantık, Çev. Macit Gökberk, İstanbul, 1972.

Farabî, et-Tavtia fì'l-Mantık, Farabî'nin Bazıı Manık Eserleri içinde, Neşr. ve terc. Mübahat Türker Küyel, Ankara, 1990.

Gökberk, Macit, Felsefe Tarihi, 5. Bsk., İstanbul, 1985.

Grünberg, Teo, Sembolik Mantık El Kitabı (Temel Mantık), cilt 1, METU Press, Ankara, 2000.

Grünberg, Teo, Sembolik Mantık El Kitabı (Sembolik Mantığın Uygulamalart), 3. C., METU Press, Ankara, 2000.

Hızır, Nusret, "Bir Mantık Tanımı Münasebetiyle", AÜDTCF.D., C. V., say. 3, MayısHaziran, 1947.

Hızır, Nusret, Çağdaş Düşünce-Mantık Meselesi, tarihsiz, Yay. Haz. Efdal Emiroğlu, Fethi Baycin.

Hızır, Nusret, Felsefe Yazıları, 2. Bsk., İstanbul. Aralık, 1981.

Inam, Ahmet, Edmund Husserl Felsefesinde Mantık, Ankara, 1995.

69. Teo Grünberg, Sembolik Mantık El Kitabı (Temel Mantık), cilt I, METU Press, Ankara, 2000 , s. 1-2. 
Kant, Immanuel, Ahlak Metafiziğinin Temellendirilmesi, Çev. İonna Kuçuradi, H. Ü. Yay., Ankara, 1982.

Lukasiewicz, Jan, Aristotle's Syllogistic, Oxford The Clarendon Press, 1954.

Öner, Necati, Fransız Sosyoloji Okuluna Göre Mantığın Menşei Problemi, 2. Bsk, Ankara, 1977.

Öner, Necati, Klasik Mantık, 6. Bsk., Ankara, 1991.

Öner, Necati, Tanzimattan Sonra Türkiye'de Illim ve Mantık Anlayışı, Ankara, 1967.

Özlem, Doğan, Mantık, İstanbul, 1991.

Reichenbach, Hans, Lojistik, Çev. Vehbi Eralp, Istanbui, 1939.

Russell, Bertrand, "Aristotle's Logic", The Basic Writings of Bertrand Russell içinde Ed. By. Robert E. Egner and Leaster E. Denon, Britain 1961.

Stebbing, L.S., A Modern Introduction to Logic, U S A, 1961.

Ural, Safak, "Sembolik Mantık ve Uygulaması", Felsefe Arkivi, Sayı: 26'dan Ayrı Basım, İstanbul, 1987.

Ulken, H. Ziya, Genel Felsefe Dersleri, Ankara, 1972.

Ülken, Hilmi Ziya, Mantık Tarihi, İstanbul, 1942.

Yıldırım, Cemal, Mantık El Kitabı, Istanbul, 1976. 